\title{
SYNTHESIS OF $\triangle$-AMINOLEVULINATE BY A CHLOROPLAST STROMA PREPARATION FROM GREENING BARLEY LEAVES
}

\author{
by \\ SIMON P. GOUGH \\ and \\ C. GAMINI KANNANGARA \\ Department of Physiology, Carlsberg Laboratory \\ Gamle Carlsberg Vej 10, DK-2500 Copenhagen, Valby
}

Keywords: Chloroplast development, $\delta$-aminolevulinate synthesizing enzyme

Synthesis of $\delta$-aminolevulinate is demonstrated in stroma preparations of plastids isolated from greening barley leaves. The soluble protein fraction from developing plastids catalyzed the conversion of glutamate into $\delta$-aminolevulinate in the presence of $0.5 \mathrm{mM}-\mathrm{ATP}, 0.25 \mathrm{mM}-\mathrm{NADPH}$ and $10 \mathrm{mM}-\mathrm{MgCl}_{2}$.

\section{INTRODUCTION}

The synthesis of $\delta$-aminolevulinate (ALA) in higher plants has been actively investigated in recent years $(1,2,4,6,8,9,10,11)$ but there is little information on the enzyme or enzymes involved, because of the difficulties encountered in obtaining active organelle-free preparations. LOHR and FRIEDMANN partially purified two enzymes from maize leaf extracts, one catalyzing the conversion of $\alpha$-ketoglutarate into dioxo- valerate in the presence of NADH and the other involved in the transamination of dioxovalerate into ALA (8). The latter enzyme has been observed also in extracts of Chlorella and Phaseolus (4). In this paper we describe a crude enzyme preparation which converts Lglutamate into ALA and has properties different to that described by LOHR and FRIEDMANN. 


\section{MATERIALS AND METHODS}

\subsection{Plant material}

Barley cultivar Svalöf's Bonus was grown on moist vermiculite in complete darkness for 6 days. Seedlings were then illuminated for 6 hours with "Osram Fluora" fluorescent lights. Leaves were harvested, wrapped in aluminium foil and chilled in ice,

\subsection{Chemicals}

L-glutamate-U- ${ }^{14} \mathrm{C}$ with a specific activity of $276 \mathrm{mCi}$ per mmole and L-glutamate-1-24 $\mathrm{C}$ with a specific activity of $55 \mathrm{mCi}$ per mmole were obtained from The Radiochemical Centre, Amersham, England.

\subsection{Organelle free and soluble enzyme preparation}

The method involves the isolation of intact plastids, washing and then disrupting them using an Aminco French pressure cell followed by ultracentrifugation. All procedures were carried out at $0^{\circ} \mathrm{C}$.

Precooled leaves were homogenized in a Braun homogenizer fitted with razor blades (7) in a medium containing $0.6 \mathrm{M}$-glycerol, $0.1 \mathrm{M}$ Tricine, $3 \mathrm{~mm}-\mathrm{Ca}\left(\mathrm{NO}_{3}\right)_{2}$ and adjusted to $\mathrm{pH} 7.9$ with $\mathrm{NaOH}$. Homogenates were squeezed through a single layer of $31 \mu$ mesh nylon cloth and filtered through another layer of the same material. The filtrate was then centrifuged at $1,400 \mathrm{~g}$ for $5 \mathrm{~min}$ in a Sorvall centrifuge. The pelleted chloroplasts were suspended in a washing medium (approximately $50 \mathrm{ml}$ ) using a glass rod with attached nylon cloth. The plastid suspension was centrifuged again for $5 \mathrm{~min}$ at $1,400 \mathrm{~g}$ and the pellet was resuspended in a small volume of suspension medium using a Potter Elvehjem homogenizer. The composition of washing and suspension media was $0.3 \mathrm{M}$-glycerol, $0.1 \mathrm{M}$-Tricine, $10 \mathrm{mM}-\mathrm{MgCl}_{2}$ and I mM-dithiothreitol and the pH's were adjusted to 7.9 with $\mathrm{NaOH}$. The plastid suspension was then passed through a French pressure cell at an internal cell pressure of 16,000 to 20,000 p.s.i. In the phase contrast microscope the plastids could then be seen to be completely broken.
A soluble enzyme preparation was obtained from this disrupted plastid preparation by centrifugation at $152,000 \mathrm{~g}$ for 1 hour in a Beckman L5/75 centrifuge. The supernatant obtained was almost completely devoid of chlorophyll and is referred to as soluble enzyme.

\subsection{Assay for ALA synthesis}

ALA formation was assayed using either radioactive or cold substrates. Reactions were carried out in $50 \mathrm{ml}$ conical flasks. Unless otherwise stated the $2 \mathrm{ml}$ reaction mixture contained the following: $0.3 \mathrm{M}$-glycerol, $0.1 \mathrm{M}$ Tricine, $1 \mathrm{~mm}$-dithiothreitol, $10 \mathrm{~mm}-\mathrm{MgCl}_{2}$, $0.25 \mathrm{~mm}$-NADPH, $0.5 \mathrm{mM}$-ATP, $2.5 \mu \mathrm{Ci}(5 \mu \mathrm{M})$ of L-glutamate-U-14 $\mathrm{C}$ or $1 \mathrm{mM}$-cold L-glutamate and soluble enzyme preparation obtained from plastid preparations containing 100-200 $\mu \mathrm{g}$ chlorophyll. The $\mathrm{pH}$ of the assay medium was adjusted to 7.9 with $\mathrm{NaOH}$. In some experiments ATP and/or NADPH were supplied by generating systems. The ATP generating system consisted of $0.5 \mathrm{mM}$-ATP, $8 \mathrm{~mm}$-creatinine phosphate and 8 units of creatine phosphokinase. The NADPH generating system consisted of $0.25 \mathrm{mM}-\mathrm{NADPH}, 6 \mathrm{mM}$-glucose-6phosphate and 0.6 units of glucose-6-phosphate dehydrogenase. Incubations were carried out at $22^{\circ} \mathrm{C}$ for $15 \mathrm{~min}$ in a shaking water bath. Illumination was provided by two $20 \mathrm{~W}$ "Osram Fluora" fluorescent strip lights held $40 \mathrm{~cm}$ from the flasks. Reactions were terminated by cooling flasks on ice, adding $100 \mu \mathrm{g}$ of carrier ALA followed by $100 \mu$ l of cold $70 \% \mathrm{HClO}_{4}$. In assays using non-radioactive substrates, carrier ALA was omitted.

\subsection{ALA analysis}

ALA formed during incubations was purified by Dowex $50 \quad$ W-X8 cation exchange chromatography, derivation to a pyrrole, solvent extraction and thin layer chromatography. This last chromatography step was omitted in assays using non-radioactive substrates. ALApyrrole was eluted from the chromatogram and the recovery of ALA and counts determined. All these procedures are described in detail in a previous publication (5). 
Table 1

Cofactor requirements for ALA synthesis with disrupted plastids.

\begin{tabular}{|c|c|c|c|c|}
\hline Experiment & $\begin{array}{c}\text { Chlorophyll } \\
\mu \mathrm{g}\end{array}$ & Incubation mixture & $\underset{\mathrm{mM}}{\mathrm{MgCl}_{2}}$ & $\begin{array}{c}\text { L-glutamate-U-U-14 C } \\
\text { incorporation in ALA } \\
\mathrm{cpm}\end{array}$ \\
\hline \multirow[t]{2}{*}{ 1. (in light) } & 290 & $\begin{aligned} \text { basic } & +50 \mathrm{~mm}-\mathrm{Na}_{2} \mathrm{HPO}_{4} \\
& +25 \mathrm{~mm}-\text { levulinate } \\
& +0.5 \mathrm{M}-\mathrm{CoA} \\
& +10 \mu \mathrm{M} \text {-acetate }\end{aligned}$ & 25 & 18,446 \\
\hline & $\begin{array}{l}290 \\
290 \\
290\end{array}$ & $\begin{array}{l}\text {-ATP } \\
\text {-levulinate } \\
\text {-coenzyme A }\end{array}$ & $\begin{array}{l}25 \\
25 \\
25\end{array}$ & $\begin{array}{r}1,876 \\
21,645 \\
35,796\end{array}$ \\
\hline \multirow[t]{2}{*}{ 2. (in light) } & 315 & $\begin{aligned} \text { basic } & +50 \mathrm{~mm}-\mathrm{Na}_{2} \mathrm{HPO}_{4} \\
& +25 \mathrm{~mm}-\text { levulinate } \\
& +0.5 \mathrm{mM}-\mathrm{CoA} \\
& +10 \mathrm{~mm} \text {-acetate }\end{aligned}$ & 10 & 20,212 \\
\hline & 315 & -NADPH & 10 & 5,542 \\
\hline $\begin{array}{l}\text { 3. in light } \\
\text { in dark }\end{array}$ & $\begin{array}{l}48 \\
48\end{array}$ & $\begin{array}{l}\text { basic } \\
\text { basic }\end{array}$ & $\begin{array}{l}21 \\
21\end{array}$ & $\begin{array}{l}57,704 \\
67,882\end{array}$ \\
\hline \multirow[t]{2}{*}{ 4. (in light) } & 136 & basic $+10 \mu \mathrm{M}$-acetate & 10 & 185,508 \\
\hline & 136 & -acetate & 10 & 228,922 \\
\hline
\end{tabular}

The plastids were prepared and disrupted as described under 2.3. The basic incubation mixtures are given under 2.4. In experiments 1 and 2 the washing and suspension medium also contained $50 \mathrm{mM}-\mathrm{Na}_{2} \mathrm{HPO}_{4}$. In experiment 3 the ATP and the NADPH and in experiment 4 the ATP were provided by the generating systems.

\subsection{Chlorophyll determination}

Chlorophyll determinations were carried out by the method of BRUINSMA (3).

\section{RESULTS}

ALA synthesis in preparations of disrupted plastids was stimulated by ATP and NADPH (Table I). Light (or aerobic conditions, data not given) which in isolated plastids greatly stimulate incorporation of labelled substrates into ALA (6), had no effect on the incorporation of $\mathrm{L}$-glutamate-U $-{ }^{14} \mathrm{C}$ into ALA catalyzed by disrupted plastids. These findings support the conclusion (6) that in intact plastids light stimulates ALA formation indirectly by providing ATP and NADPH. The addition of levulinate $(25 \mathrm{mM})$ was no longer required for accumulation of ALA. The addition of $0.5 \mathrm{~mm}$ -
CoA or $10 \mu \mathrm{M}$-acetate inhibited the incorporation by $49 \%$ and $19 \%$ respectively.

The effect of varying $\mathrm{MgCl}_{2}$ and NADPH concentrations on ALA formation is given in Figure 1. Incorporation of $\mathrm{L}$-glutamate- $\mathrm{U}-{ }^{14} \mathrm{C}$ into ALA increased linearly with $\mathrm{MgCl}_{2}$ concentrations from 5 to $20 \mathrm{mM}$ and levelled off thereafter. NADPH was optimal at a concentration of $0.05 \mathrm{~mm}$ as was also observed with NADH.

These experiments were carried out with plastids disrupted in the presence of $50 \mathrm{mM}$ $\mathrm{Na}_{2} \mathrm{HPO}_{4}$. When plastids were prepared, disrupted and incubated in the absence of $50 \mathrm{mM}$ $\mathrm{Na}_{2} \mathrm{HPO}_{4}$ (Table I, experiments 3 and 4) ALA synthesis was more than ten-fold higher than in its presence (experiments 1 and 2). The requirement for high $\mathrm{Mg}^{2+}$ concentration was then less pronounced, suggesting that the inhibitory ef- 


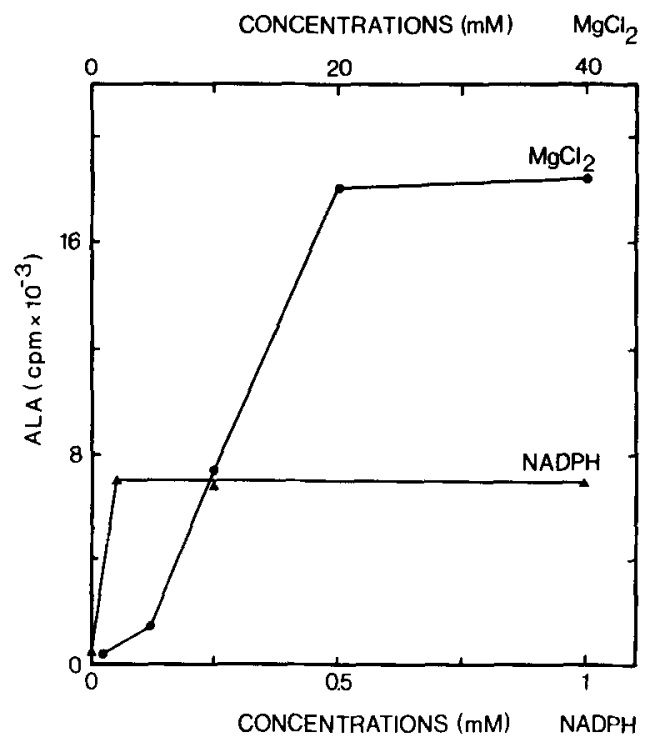

Figure 1. The effect of different concentrations of $\mathrm{MgCl}_{2}$ and $\mathrm{NADPH}$ on the incorporation of $\mathrm{L}$ glutamate-U $-{ }^{14} \mathrm{C}$ into ALA. Chloroplasts were disrupted in a medium containing $0.3 \mathrm{M}$-glycerol, $0.1 \mathrm{M}$ Tricine, $50 \mathrm{~mm}-\mathrm{Na}_{2} \mathrm{HPO}_{4}, 1 \mathrm{mM}$-dithiothreitol and disrupted chloroplasts $(200 \mu \mathrm{g}$ chlorophyll) incubated in a medium containing in addition $0.5 \mathrm{mM}-\mathrm{ATP}, 0.5$ $\mathrm{mM}-\mathrm{CoA}, 10 \mu \mathrm{M}$-acetate, $25 \mathrm{~mm}$-levulinate and 2.5 $\mu \mathrm{Ci}$ L-glutamate. In incubations containing 0 to 40 $\mathrm{mM}-\mathrm{MgCl}_{2}, 0.25 \mathrm{~mm}-\mathrm{NADPH}$ was present and in incubations containing 0 to $1 \mathrm{mM}-\mathrm{NADPH}, 10 \mathrm{mM}$ $\mathrm{MgCl}_{2}$ was included. All incubations were carried out for $15 \mathrm{~min}$ at $22^{\circ} \mathrm{C}$.

fect of phosphate is due to the removal of $\mathrm{Mg}^{2+}$. Label from both ${ }^{1-{ }^{14}} \mathrm{C}$ and $\mathrm{U}^{-14} \mathrm{C}$ glutamate was incorporated into ALA to about the same extent by disrupted plastid preparations.

After high speed centrifugation of disrupted plastids the ALA-synthesizing activity was associated with the soluble protein fraction (Table II). Addition of the green membrane fraction to the soluble enzyme(s) inhibited the incorporation of L-glutamate-U- ${ }^{14} \mathrm{C}$ into ALA by $35 \%$. Both NADPH and NADH served as a reductant for the conversion of glutamate into ALA by the soluble enzyme(s) (Table III). NADPH was a more effective reductant compared to NADH. The incorporation supported by NADP is probably due to the presence of en-
Table II

Localization of ALA synthesizing activity in the soluble protein (stroma) fraction of greening plastids.

\begin{tabular}{|c|c|c|}
\hline Fractions & $\begin{array}{r}\text { L-gluta } \\
\text { incor } \\
\text { int }\end{array}$ & $\begin{array}{l}\text { e-U-14C } \\
\text { ation } \\
\text { A }\end{array}$ \\
\hline \multirow{2}{*}{\multicolumn{2}{|c|}{$\begin{array}{l}\text { Membranes }(0.9 \mathrm{ml} \sim 286 \mu \mathrm{g} \text { chlorophyll }) \\
\text { Soluble proteins } \\
\quad(0.9 \mathrm{ml} \sim 13 \mu \mathrm{g} \text { chlorophyll })\end{array}$}} & 635 \\
\hline & & 16,056 \\
\hline \multicolumn{2}{|l|}{$\begin{array}{l}\text { Membranes } \\
(0.9 \mathrm{ml})+\text { soluble proteins }\end{array}$} & 10,496 \\
\hline
\end{tabular}

Isolated plastids were washed in the basic medium + $50 \mathrm{~mm}-\mathrm{Na}_{2} \mathrm{HPO}_{4}$ and disrupted in this medium after addition of $10 \mathrm{mM}-\mathrm{MgCl}_{2}$. Eight $\mathrm{ml}$ of disrupted plastids ( $315 \mu \mathrm{g}$ chlorophyll per $\mathrm{ml}$ ) were centrifuged for 15 min at $133,000 \mathrm{~g}$ in a Beckman L5/75 centrifuge at $4^{\circ} \mathrm{C}$. The green pellet is referred to as the membrane fraction. It was suspended in phosphate and $\mathrm{MgCl}_{2}$ containing medium and made up to $8 \mathrm{ml}$. The supernatant from the top af the centrifuge tube was greenish yellow and is referred to as the soluble protein fraction. Incubations were with $0.5 \mathrm{~mm}-\mathrm{ATP}$, $0.5 \mathrm{~mm}$-coenzyme A, $25 \mathrm{~mm}$-levulinate, $10 \mu \mathrm{M}$-acetate, $2.5 \mu \mathrm{Ci} \mathrm{L}$-glutamate- $\mathrm{U}^{14} \mathrm{C}$ and additional $\mathrm{MgCl}_{2}$ to give $25 \mathrm{~mm}$ for $15 \mathrm{~min}$ at $22^{\circ} \mathrm{C}$ in light.

\section{Table III}

The specificity of pyridine nucleotides as cofactors for ALA synthesis and the stability of the enzymatic activity.

\begin{tabular}{c|c}
\hline Pyridine nucleotide added & $\begin{array}{c}\text { L-glutamate-U- }{ }^{14} \mathrm{C} \\
\text { incorporation } \\
\text { into ALA } \\
\text { cpm }\end{array}$ \\
\hline
\end{tabular}

$\begin{array}{lr}\text { With freshly prepared enzyme } & \\ \text { none } & 2,264 \\ 0.25 \text { mM-NADPH } & 19,252 \\ 0.5 \text { mM-NADP } & 9.945 \\ 0.25 \text { mM-NADH } & 12,177 \\ 0.5 \text { mM-NAD } & 1,863\end{array}$

With enzyme stored for 16 hours at $\div 20^{\circ} \mathrm{C}$ $0.25 \mathrm{mM}-\mathrm{NADPH}$

15,067

Plastids (208 $\mu \mathrm{g}$ chlorophyll per $\mathrm{ml}$ ) were disrupted in a medium containing $0.3 \mathrm{M}$-glycerol, $0.1 \mathrm{M}$-Tricine, 50 $\mathrm{mM}-\mathrm{Na}_{2} \mathrm{HPO}_{4}, 1 \mathrm{~mm}$-dithiothreitol, $25 \mathrm{mM}-\mathrm{MgCl}_{2}$ and centrifuged for 1 hour at $152,000 \mathrm{~g}$. Aliquots $(1 \mathrm{ml})$ of the supernatant were incubated with $0.5 \mathrm{mM}$-ATP, 0.5 mM-Coenzyme A, $10 \mu \mathrm{M}$-acetate, $25 \mathrm{~mm}$-levulinate, $2.5 \mu \mathrm{Ci} \mathrm{L}$-glutamate- $\mathrm{U}^{14} \mathrm{C}$ in a total volume of $2 \mathrm{ml}$ for $15 \mathrm{~min}$ at $22^{\circ} \mathrm{C}$. 


\section{Table IV}

Demonstration of ALA synthesis by the soluble protein fraction (stroma) of greening barley plastids using nonradioactive substrates.

\begin{tabular}{l|c|c}
\hline Substrate added & $\begin{array}{c}\text { Incubation } \\
\text { min }\end{array}$ & $\begin{array}{c}\text { Amount of } \\
\text { ALA detected } \\
\text { nmoles }\end{array}$ \\
\hline none & 0 & 1.7 \\
none & 20 & 4,4 \\
1 mM-L-glutamate & 20 & 8.8 \\
1 mM-a-ketoglutarate & 20 & 5.9 \\
\hline
\end{tabular}

Incubations were carried out with $2 \mathrm{ml}$ soluble protein fraction of chloroplast (equivalent to $192 \mu \mathrm{g}$ chlorophyll) in the presence of $21 \mathrm{mM}-\mathrm{MgCl}_{2}$, ATP and NADPH generating systems. ALA formed was purified, converted to the pyrrole and assayed spectrophotometrically according to 2.5 .

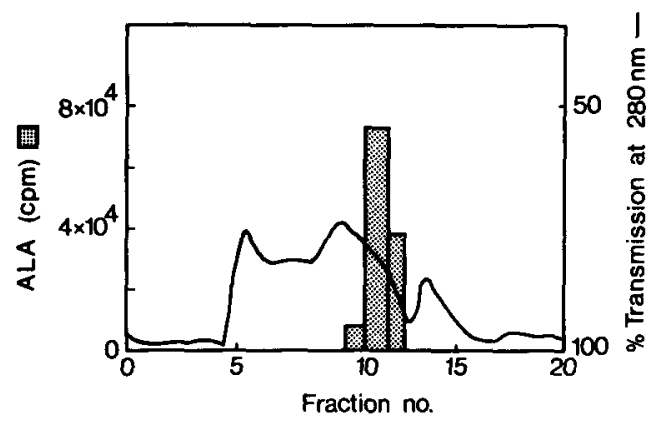

Figure 2. Elution pattern of the barley ALA-synthesizing enzyme in Sepharose 6-B chromatography. A soluble protein fraction from developing chloroplasts $(2 \mathrm{ml} \sim 192 \mu \mathrm{g}$ chlorophyll) was loaded on to a Sepharose 6-B column $(1.5 \times 24 \mathrm{~cm})$ preequilibrated with $0.3 \mathrm{M}$-glycerol, $0.1 \mathrm{M}$-Tricine, 0.5 mM-dithiothreitol, adjusted to $\mathrm{pH} 7.9$ with $\mathrm{NaOH}$ and was eluted with the same buffer. Eluate was monitored for u.v. light absorption using a LKB Uvicord II. Fractions $(3.5 \mathrm{ml})$ were collected and assayed for ALA-synthesis.

zymes converting NADP into NADPH. A soluble enzyme preparation stored at $-20^{\circ} \mathrm{C}$ for 16 hours had retained $80 \%$ of the ALA-synthesizing activity. The soluble enzyme preparation was sufficiently active to be used with nonradioactive substrates to give spectrophotometrically assayable amounts of ALA (Table IV). One mM-glutamate increased ALA formation two-fold whereas $\alpha$-ketoglutarate at the same concentration was less effective. ALA also accumulated in the absence of added substrate, presumably due to the presence of endogenous glutamate in the enzyme preparations.

Fractionation of the soluble chloroplast proteins from greening barley is illustrated in Figure 2. The enzyme eluted as a single peak with a low apparent molecular weight.

\section{DISCUSSION}

In intact plastids $(5,6,12)$ or in detached leaves $(1,2,9)$ significant accumulation of ALA requires the presence of levulinate to inhibit the further metabolization of ALA by ALAdehydratase. In the present paper it is shown that disruption of the plastids eliminates the requirement of levulinate for ALA accumulation. Several explanations can be proposed for the loss of effective metabolization of ALA by ALA-dehydratase upon breakage of the plastids, e.g., ALA-dehydratase may have to be closely associated with the ALA-synthesizing enzyme to function properly and this association is lost by the disruption. Alternatively in the homogenate ALA-dehydratase may be inhibited by an endogenous compound or one of the added cofactors such as ATP (11).

Many ATP linked enzymes require $\mathrm{Mg}^{2+}$ for activity and a concentration of $0.5 \mathrm{mM}$ is satisfactory. In the present experiments rather high concentrations of $\mathrm{MgCl}_{2}$ were necessary to obtain significant ALA-synthesis. Further studies are needed to show if this signifies that $\mathrm{Mg}^{2+}$ is required for stabilization or activation of the enzyme.

We have tentatively designated the partially purified enzyme as a stroma localized enzyme, but that does not exclude a loose association with the thylakoids in the intact plastids.

\section{ACKNOWLEDGEMENTS}

The authors are most grateful to Ms. SUSANNE PLACING for her skilled technical assistance and also to the following for their skilful help. Ms. NINA RASMUSSEN for drawing the figures, Ms. AnN-Sofi Steinholtz for the photography, Ms. LENA KONGSRUD for typing 
the manuscript and Mr. BøRGE PETERSEN for the growth of plants. We should also like to thank prof. DITER VON WETTSTEIN for his help and criticism with the preparation of the manuscript. This work was supported by grant GM-22051 of the USPHS National Institutes of Health to professor D. vON WETTSTEIN.

\section{REFERENCES}

1. Beale, S. I. \& P. A. Castelfranco: The biosynthesis of $\delta$-aminolevulinic acid from labelled precursors in greening plant tissues. Plant Physiol. 53, 297-303 (1974)

2. Beale, S. I., S. P. Gough \& S. Granick: Biosynthesis of $\delta$-aminolevulinic acid from the intact carbon skeleton of glutamic acid in greening barley. Proc. Nat. Acad. Sci. USA 72, 2719-2723 (1975)

3. BRUinsma, J.: A comment on the spectrophotometric determination of chlorophyll. Biochim. Biophys. Acta. 52, 576-578 (1961)

4. Gassman, M. L., J. Pluscec \& L. Bogorad: $\delta$. aminolevulinic acid transaminase in Chlorella Vulgaris. Plant Physiol. 43, 1411-1414 (1968)

5. Gough, S. P. \& C. G. KanNangara: Synthesis of $\delta$-aminolevulinic acid by isolated plastids. Carlsberg Res. Commun. 41, 183-190(1976)
6. Kannangara, C. G. \& S. P. Gough: Synthesis of $\delta$ aminolevulinic acid and chlorophyll by isolated chloroplasts. Carlsberg Res. Commun. 42, 441. 458 (1977)

7. Kannangara, C. G., S. P. Gough, B. Hansen, J. N. RASMUSSEN \& D. J. SIMPSON: A homogenizer with replaceable razor blades for bulk isolation of active barley plastids. Carlsberg Res. Commun 42, 431-440 (1977)

8. Lohr, J. B. \& H. C. FriedmanN: New pathway for $\delta$-aminolevulinic acid biosynthesis: Formation from $a$-ketoglutaric acid by two partially purified plant enzymes. Biochem. Biophys. Res. Commun. 69, 908-913(1976)

9. Meller, E., S. Belkin \& E. Harel: The biosynthesis of $\delta$-aminolevulinic acid in greening maize leaves. Phytochemistry 14, 2399-2402 (1975)

10. Nadler, K. \& S. Granick: Control on chlorophyll synthesis in barley. Plant Physiol. 46, 240$246(1970)$

11. NANDI, D. L. \& E. R. WAYGOOD: Biosynthesis of porphyrins in wheat leaves II. 5-aminolevulinate hydro-lyase. Can. J. Biochem. 45, 327-336 (1967)

12. Weinstein, J. D. \& P. A. Castelfranco: Incorporation of ${ }^{14} \mathrm{C}$-glutamate in 5-aminolevulinic acid (ALA) by isolated chloroplasts. Plant. Physiol. 52 suppl., 92 (1977) 